\title{
COMPATIBILITY OF RENEWABLE ENERGIES WITH THE STANDARDS OF ENERGY MANAGEMENT SYSTEM AND ENVIRONMENTAL DESIGN OF GREEN BUILDINGS
}

\author{
Nourhan Mohamed Subhi Sharaf El-Din*, Mohamed Salah el-Din el-Said, Wael Seddik \\ Moustafa and Heba Mohamed Abdou \\ Architecture Engineering, Faculty of Engineering Mansoura University, Mansoura, Egypt \\ * Corresponding Author E-mail: nourham.m.subhi@ gmail.com
}

\begin{abstract}
The world today faces challenges in the form of population growth, resource consumption, environmental degradation, climate change and energy crises. Unless some immediate remedial measures are taken, things are expected to get worse. There is a need to protect the environment by preserving it through the production of clean energy, represented by new and renewable energies, to deal with energy problems and environmental degradation. The close link between development and environment has led to a phenomenon called sustainability, which requires attention to environmental protection, taking into account that renewable energies are one of the most important means of protecting the environment. Therefore, many countries are now developing renewable energy sources and set a goal to achieve the efficiency of the built environment and face future environmental challenges and construction. The paper presents the relationship between the use of renewable energies and the adoption of building design as sustainable buildings. The aims of the study are that there is a direct positive relationship between the use of properties acquired by renewable energies as a complementary method in the field of energy efficiency in buildings and the adoption of sustainable building design, according to one of the most important global sustainable building assessment systems, the system of energy leadership and environmental design (LEED). Determining the number of points that the use of renewable energies can contribute and is appropriate to the total number of points for all determinants and strategies of sustainability in global building sustainability assessment systems.
\end{abstract}

\section{KEY WORDS: Renewable Energy, Renewable Energy Sources, Sustainability Issues, LEED (Leadership And Environmental Design), Envi ronmental Sustainability Engineering.}

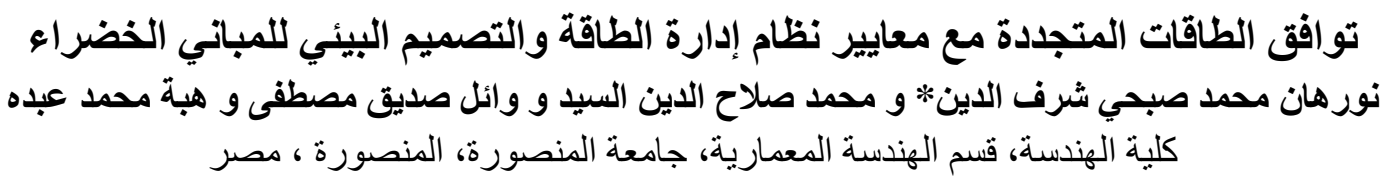

البريد الاليكتروني للباحث الرئيسي: E-mail: nourham.m.subhi@gmail.com

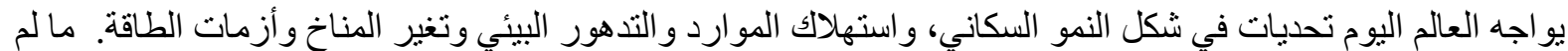

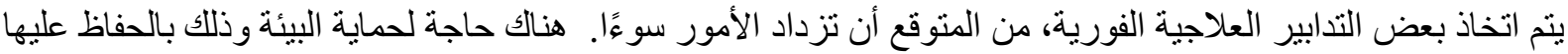

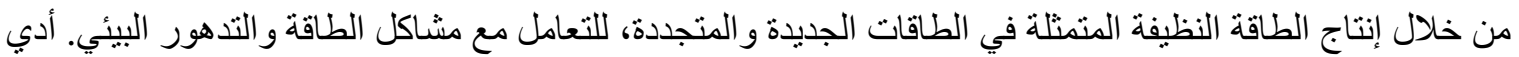
الارتباط الوثيق بين التتمية والبيئة إلى ظهور ما يسمى الا ستدامة، الأمر الذي يستلزم الانتمام بحماية البيئة، مع اخذ في لئي 


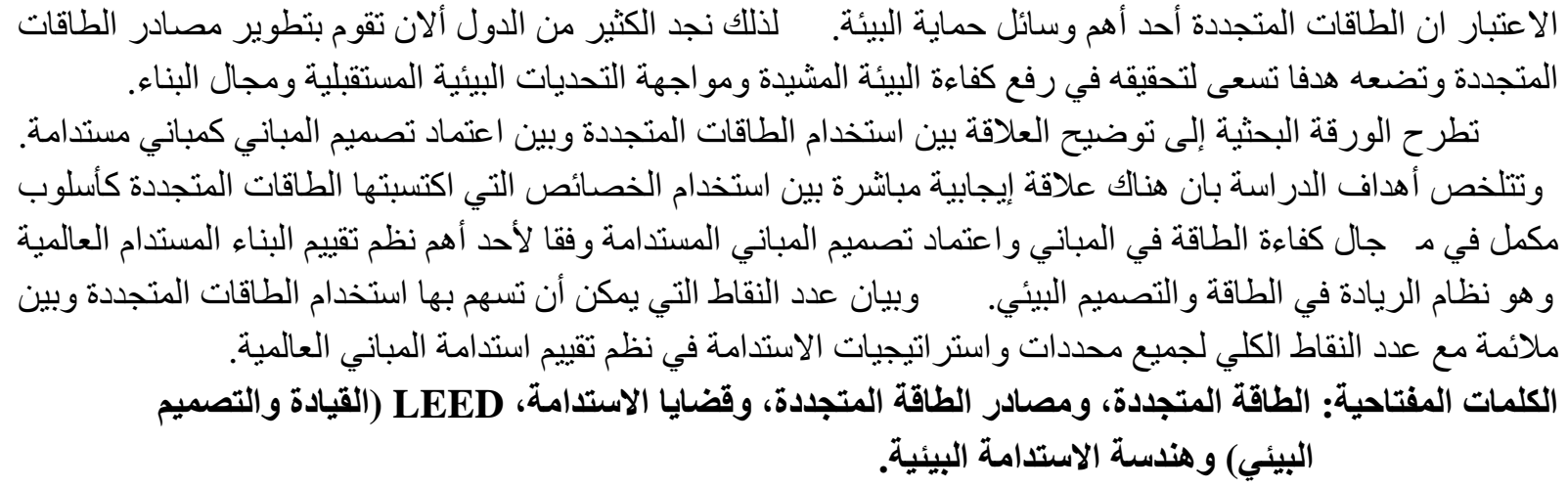

\section{INTRODUCTION}

The study search for examining the potential and trends in sustainable development with renewable energy sources, there is a positive connection between the usage of properties learned by renewable energies an additional technique in the field of construction and strategy of the buildings sustainability environmentally friendly resources with the ratings developed in the light of sustainable international construction assessment systems. (Cohen, 2007)

Stimulated by recent technological advances and growing concern over the sustainability and environmental impression of conventional fuel usage, the scene of creating clean, sustainable power in substantial measures from renewable energy sources produces interest around the world. This paper provides a complete overview of the major types of renewable energy-including solar, thermal, photovoltaics, bioenergy, hydro, tidal, wind, wave, and geothermal. It studies the environmental effect and predictions of different energy sources. (Boyle, 2004)

\section{RENEWABLE ENERGY AND SUSTAINABLE DEVELOPMENT}

Renewable energy directly related to sustainable development through its effect on human development and economic production. The convenience of renewable energy sources and energy security, chances for social and economic development, and admission to energy, and the justification of climate transformation and the decrease of environmental and health effects. (Asumadu-Sarkodie, 2016)

\section{RENEWABLE ENERGY RESOURCES AND TECHNOLOGY}

Renewable sources of energy knowledge and renewable energy sources are bases of energy from ordinary and continuous flow of energy happens in the direct environment. They include: direct vital energy, solar energy and geothermal energy and hydropower, wind energy, biomass energy, waste material energy, ocean and waves energy. (Bull, 2001)

Solar energy:

The word "direct" solar energy mentions the energy base for those renewable energy source technologies that draw on the Sun's energy directly, shown in Figure (1). Some renewable knowledges, such as wind and ocean thermal, use solar energy next to it has been fascinated on the earth and transformed to the other forms. Solar energy skills is obtained from solar irradiance to produce electricity using photovoltaic (PV) (Asumadu-Sarkodie, 2016) and concentrating solar power (CSP), to produce thermal energy, to meet direct lighting needs and, potentially', to

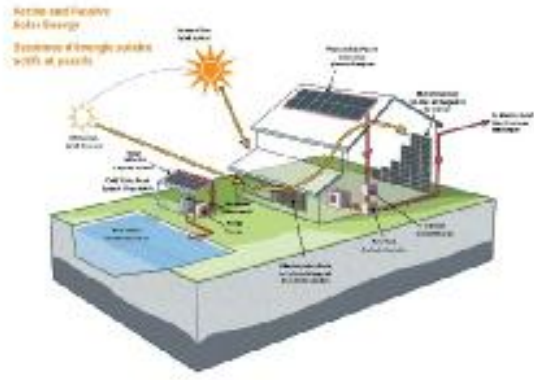

Figure (1) Active and passive solar energy ((NREL), 2018)

produce fuels that could be used for transportation and other resolutions (Edenhofer, 2011). Solar energy can be applied in form of active solar energy and passive solar energy. According to the World Energy Council (Council, 2013) "the total energy from solar 
radiation which radiates on the earth was more than 7,500 times the World's total annual principal energy consumption of 450 EJ" (Urban, 2011).

\section{Wind Energy}

Winds generates several layers of the atmosphere absorb different quantities of heat and develop differently. For countries, wind energy used to sail ships and pump water (Ahmed, 2015). To creates the maximum electricity possible, wind turbines want to be placed in areas wherever the wind blows at a endless speed. Huge groups of wind turbines, called wind farms or wind plants, are linked to electric utility power line and offer electricity to many people which shown in Figure (2) (Zin, 2013). An advantage of wind turbines over some other forms of renewable energy is that they create electricity whenever the wind shocks (at night and also during the day). But, even in the windiest of places, the wind does not upset all the time. Consequently, small wind systems requirement back up batteries. Hillsides, mountains and open places are the top sites to set up wind turbines. (Shepherd, 2011).

Ocean energy (tide and wave)

Surface waves are generated when wind moves over water (Ocean). The more rapidly the wind speed is, the longer the wind is sustained, the bigger distance the wind moves, the

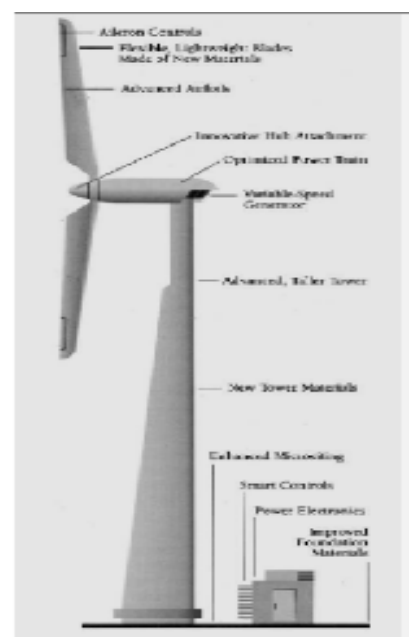

Figure (2) Modern wind turbine for utility scale power generation. (Ahmed, 2015)

larger the wave height, and the larger the wave energy formed (Jacobson, 2011). The ocean stores abundant energy to see the total worldwide request for power several times concluded in the method of waves, tide, flows and heat. The year 2008 saying the start of the first generation of commercial Ocean energy strategies. There are currently four ways of finding energy from sea zones, specifically from Wind, Tides, Waves and Thermal changes between deep and shallow Sea water as shown in Figure (3) (Esteban, 2012).

Biomass Energy

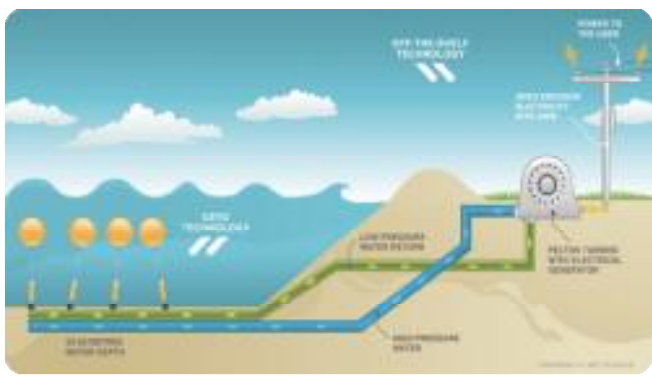

Figure 3 Oceans \& Waves Energy (Jeans, et al., 2013)

Bio-energy is the energy from bio-mass or organic material such as wood. Biomass was used for centuries, right from the time persons energy began burning wood to cook or to save warm. although wood, in various forms, still the main biomass resources for bio-energy, there are now additional sources such as farming be located in, plants, and waste materials (Hoogwijk, 2005).

The usage of bioenergy produces as much carbon dioxide such as fossil fuels, each new plant that raises removes carbon dioxide eliminated from the atmosphere, thus continuing an ecological tability, with net productions being near to zero of new plants are grownup each time an old one is burnt (Ayoub, 2012). To increase agricultural proceeds while at the same time maintain environmental stabilities, fast increasing trees and grasses can be planted (Demirbas, 2009). These plants are named Bio-Energy feed tocks'. It can be classified into three main types (Wood fuels- Agrofuels- Fuels resulting from urban waste).

Waste Materials Energy

Community solid waste has the probable to be a great source. It moderates the problem if waste clearance specially in countries There is not abundant landfill space to landfill the waste. This community solid waste can be seared in great power plants to produce electric power (Johari, 2012). Community waste-to energy plants presently produce about 2500 megawatts of electricity. There is also additional ways to trap the energy in garbage. When food scraping and wastes decline, methane, a green-house gas with 22 time the global warming probable of carbon dioxide is formed. It can be collected, cleaned and seared to form steam in a boiler or energy producers coproduce electricity (Johari, 2012). 


\section{Hydropower energy}

Power from the water in the rivers and streams is identified as hydropower, or hydroelectric power is between the most usually used forms of renewable energy in the world. It accounts for about $20 \%$ of worldwide electricity stock. The greatest mutual method in which hydroelectric power plant works can be summarized in the following Figure (4). (Edenhofer, 2011) Hydropower is an important energy source attached from water moving from top to low elevation levels, mainly to turn turbines and produce electricity. Hydropower projects consist of Dam project with reservoirs, run-of-river and in-stream projects and cover a range in project scale. (Finn R, 2015)


Figure (4) Principal of Hydroelectric Power Generation, and typical applications of dam. (Edenhofer, 2011)

\section{Geothermal energy}

Geothermal energy increased obviously from the earth's central as heat energy source. The source of the heat is associated with the inner structure of the earth and the physical procedures taking place there. While warmth is existing in the earth's top in huge extents, not to remark the deepest parts, it is irregularly scattered, rarely concerted, and often at depths also great to be broken mechanically.

Geothermal rise averages about $30^{\circ} \mathrm{C} / \mathrm{km}$. There are parts of the earth's interior which are available by penetrating.(Barbier, 2002).

Heat is extracted from geothermal reservoirs using wells and other resources. Reservoirs that are obviously sufficiently hot and permeable are named hydrothermal reservoirs, while tanks that are acceptably hot but are upgraded with hydraulic stimulation are named enhanced geothermal systems (ESG). Once strained to the surface, fluids of several temperatures used to produce electricity and other determinations that involve the usage of heat energy (Edenhofer, 2011).

\section{Renewable energy and sustainable development}

Renewable energy has straight relationship with sustainable progress through its effect on human growth and economic production (Asumadu-Sarkodie, 2016). Renewable energy bases provide occasions in energy security, social and economic development, climate change justification and the reduction of environmental and health effects (Asumadu-Sarkodie, 2016). Compatibility of Renewable Energies with the standards of energy management system and environmental design of green buildings:

System assessment points are calculated by obtaining one or more green squares according to LEED points in any cell resulting from the intersection of the Sustainability Assessment Criterion with the properties of the renewable energies. This means that this property has an impact that will get the points necessary to meet sustainability criteria. Shaded squares in a row will not give greater points. 


\begin{tabular}{|c|c|c|c|c|c|c|c|c|}
\hline $\begin{array}{c}\text { LEED } \\
\text { V.3-2009 NC }\end{array}$ & \multicolumn{7}{|c|}{ Renewable energy with sustainable future architecture } & \multirow{2}{*}{$\begin{array}{r}\begin{array}{r}\text { Total } \\
\text { points } \\
\text { added }\end{array} \\
17 / 26\end{array}$} \\
\hline \multirow{2}{*}{ 1-Sustainable Sites } & \multirow{2}{*}{$\begin{array}{c}\text { Solar } \\
\text { Energy }\end{array}$} & \multirow{2}{*}{$\begin{array}{l}\text { Wind } \\
\text { Energy }\end{array}$} & \multirow{2}{*}{$\begin{array}{l}\text { Ocean \& } \\
\text { Waves } \\
\text { Energy }\end{array}$} & \multirow{2}{*}{$\begin{array}{c}\text { Biomass } \\
\text { Energy }\end{array}$} & \multirow{2}{*}{$\begin{array}{c}\text { waste } \\
\text { material } \\
\text { Energy }\end{array}$} & \multirow{2}{*}{$\begin{array}{l}\text { Hydropow } \\
\text { er Energy }\end{array}$} & \multirow{2}{*}{$\begin{array}{l}\text { Geothe } \\
\text { rmal } \\
\text { Energ } \\
\quad y\end{array}$} & \\
\hline & & & & & & & & $16 / 26$ \\
\hline $\begin{array}{l}\text { Protection from } \\
\text { pollution } \\
\text { resulting from } \\
\text { construction }\end{array}$ & \multicolumn{7}{|c|}{$\begin{array}{l}\text { Aimed at reducing the pollution resulting from the various construction } \\
\text { activities and methods of controlling the rates of soil erosion and } \\
\text { sedimentation in the waterways and the generation of harmful dust and } \\
\text { dust }\end{array}$} & Basic \\
\hline Site Selection & \multicolumn{7}{|c|}{$\begin{array}{l}\text { Avoid developing unsuitable sites for the nature of the project and } \\
\text { reduce the impact of the passive building site on the surrounding } \\
\text { environment. }\end{array}$} & $1 / 1$ \\
\hline \multirow{2}{*}{$\begin{array}{l}\text { Development } \\
\text { Density and } \\
\text { Community } \\
\text { Connectivity }\end{array}$} & \multicolumn{7}{|c|}{ Aims to link urban development plans with available infrastructure } & \multirow[b]{2}{*}{$0 / 5$} \\
\hline & & & & & & & & \\
\hline $\begin{array}{l}\text { Brownfield } \\
\text { Redevelopment }\end{array}$ & \multicolumn{7}{|c|}{$\begin{array}{l}\text { Aims to rehabilitate or develop areas of waste, contaminants and } \\
\text { abandoned areas, which contain a high percentage of pollutants }\end{array}$} & $1 / 1$ \\
\hline \multirow{2}{*}{$\begin{array}{l}\text { Alternative } \\
\text { transportation } \\
\text { (Public } \\
\text { Transportation } \\
\text { Access - Bicycle } \\
\text { Storage and } \\
\text { Changing } \\
\text { Rooms - Low- } \\
\text { Emitting and } \\
\text { Fuel-Efficient } \\
\text { Vehicles - } \\
\text { Parking } \\
\text { Capacity) }\end{array}$} & \multicolumn{7}{|c|}{$\begin{array}{l}\text { Aims to reduce the impact of pollution resulting from the use of cars and } \\
\text { reduce all negative environmental impacts on the environment resulting } \\
\text { from the operation of their service projects }\end{array}$} & \multirow[b]{2}{*}{$12 / 12$} \\
\hline & & & & & & & & \\
\hline \multirow{2}{*}{$\begin{array}{l}\text { Site } \\
\text { development } \\
\text { (Protect or } \\
\text { Restore Habitat } \\
\text { - Maximize } \\
\text { Open Space) }\end{array}$} & \multicolumn{7}{|c|}{$\begin{array}{l}\text { Aims to protect natural sites from the negative effects of building and the } \\
\text { operation and maintenance of damaged sites and increase the proportion } \\
\text { of open spaces to increase the scope of biodiversity }\end{array}$} & \multirow[t]{2}{*}{$0 / 2$} \\
\hline & & & & & & & & \\
\hline $\begin{array}{l}\text { Stormwater } \\
\text { design (Quantity } \\
\text { and Quality } \\
\text { Control) } \\
\end{array}$ & \multicolumn{7}{|c|}{$\begin{array}{l}\text { The aim is to reduce the damage to natural water hydrology by reducing non- } \\
\text { leaking surfaces and increasing the leakage through the surface of the water at } \\
\text { the site and reduce the pollution by increasing the rate of runoff and pollution } \\
\text { reduction. }\end{array}$} & $\mathbf{0} / 2$ \\
\hline
\end{tabular}




\begin{tabular}{|c|c|c|c|c|c|c|c|c|}
\hline $\begin{array}{l}\text { Heat Island } \\
\text { Effect (Nonroof } \\
\text { - Roof) }\end{array}$ & \multicolumn{7}{|c|}{$\begin{array}{l}\text { Aimed at reducing the phenomenon of thermal islands developed to } \\
\text { reduce their impact on the local climate and human settlements and } \\
\text { wildlife }\end{array}$} & $2 / 2$ \\
\hline $\begin{array}{l}\text { Reduce light } \\
\text { pollution }\end{array}$ & \multicolumn{7}{|c|}{$\begin{array}{l}\text { Designed to reduce lighting consumption in building and location, reduce } \\
\text { glow and improve night vision }\end{array}$} & 1/1 \\
\hline $\begin{array}{l}\text { LEED } \\
\text { V.3-2009 NC }\end{array}$ & \multicolumn{7}{|c|}{ Renewable energy with sustainable future architecture } & $\begin{array}{l}\text { Total } \\
\text { points } \\
\text { added }\end{array}$ \\
\hline \multirow[b]{2}{*}{$\begin{array}{l}\text { 2- Water } \\
\text { Efficiency }\end{array}$} & \multirow[b]{2}{*}{$\begin{array}{l}\text { Solar } \\
\text { Energy }\end{array}$} & \multirow[b]{2}{*}{$\begin{array}{l}\text { Wind } \\
\text { Energy }\end{array}$} & \multirow{2}{*}{$\begin{array}{l}\text { Ocean } \\
\& \\
\text { Waves } \\
\text { Energy }\end{array}$} & \multirow[b]{2}{*}{$\begin{array}{l}\text { Biomass } \\
\text { Energy }\end{array}$} & \multirow[b]{2}{*}{$\begin{array}{c}\text { waste } \\
\text { material } \\
\text { Energy }\end{array}$} & \multirow{2}{*}{\multicolumn{2}{|c|}{$\begin{array}{l}\text { Hydropow } \\
\text { er Energy }\end{array}$}} & $\mathbf{0} / \mathbf{1 0}$ \\
\hline & & & & & & & & $\mathbf{0} / \mathbf{1 0}$ \\
\hline $\begin{array}{l}\text { Water efficient } \\
\text { landscaping }\end{array}$ & \multicolumn{7}{|c|}{$\begin{array}{l}\text { Aimed at reducing the use of drinking water and groundwater and } \\
\text { surface water sources near the project site in the irrigation of gardens by } \\
\text { reducing water consumption by } 50 \%\end{array}$} & $0 / 4$ \\
\hline $\begin{array}{l}\text { Innovative } \\
\text { technologies for } \\
\text { wastewater use }\end{array}$ & \multicolumn{7}{|c|}{$\begin{array}{l}\text { Aimed at reducing the generation of waste water and reducing the } \\
\text { demand for drinking water, and not to damage the stocks of local } \\
\text { aquifers }\end{array}$} & $\mathbf{0} / 2$ \\
\hline $\begin{array}{l}\text { Reduce water } \\
\text { use }\end{array}$ & \multicolumn{7}{|c|}{$\begin{array}{l}\text { Aims to raise the efficiency of water used in buildings to reduce the } \\
\text { burden on water supply systems and sewage systems }\end{array}$} & $0 / 4$ \\
\hline $\begin{array}{l}\text { LEED } \\
\text { V.3-2009 NC }\end{array}$ & \multicolumn{7}{|c|}{ Renewable energy with sustainable future architecture } & $\begin{array}{l}\text { Total } \\
\text { points } \\
\text { added }\end{array}$ \\
\hline \multirow{2}{*}{$\begin{array}{l}\text { 3- Energy \& } \\
\text { Atmosphere }\end{array}$} & \multirow{2}{*}{$\begin{array}{l}\text { Solar } \\
\text { Energy }\end{array}$} & \multirow{2}{*}{$\begin{array}{l}\text { Wind } \\
\text { Energy }\end{array}$} & \multirow{2}{*}{$\begin{array}{l}\text { Ocean } \\
\& \\
\text { Waves } \\
\text { Energy }\end{array}$} & \multirow{2}{*}{$\begin{array}{l}\text { Biomass } \\
\text { Energy }\end{array}$} & \multirow{2}{*}{$\begin{array}{l}\text { waste } \\
\text { materia } \\
\quad 1 \\
\text { Energy }\end{array}$} & \multirow{2}{*}{$\begin{array}{l}\text { Hydropo } \\
\text { wer } \\
\text { Energy }\end{array}$} & \multirow{2}{*}{$\begin{array}{l}\text { Geothe } \\
\text { rmal } \\
\text { Energy }\end{array}$} & $35 / 35$ \\
\hline & & & & & & & & $35 / 35$ \\
\hline \multirow{2}{*}{$\begin{array}{l}\text { Fundamental } \\
\text { Commissioning } \\
\text { of Building } \\
\text { Energy Systems }\end{array}$} & \multicolumn{7}{|c|}{$\begin{array}{l}\text { Appropriate to the system is that the power systems in the building have } \\
\text { been equipped and calibrated. }\end{array}$} & \multirow{2}{*}{ Basic } \\
\hline & & & & & & & & \\
\hline $\begin{array}{l}\text { Minimum } \\
\text { Energy } \\
\text { Performance }\end{array}$ & \multicolumn{7}{|c|}{$\begin{array}{l}\text { It aims to adopt the specifications adopted by the electrical authorities } \\
\text { and the efficiency of the design of the building cover, air conditioning } \\
\text { systems, lighting and other systems in order to raise the level of energy } \\
\text { performance }\end{array}$} & Basic \\
\hline
\end{tabular}




\begin{tabular}{|c|c|c|c|c|c|c|c|c|}
\hline \multirow{2}{*}{$\begin{array}{l}\text { Fundamental } \\
\text { Refrigerant } \\
\text { Management }\end{array}$} & \multicolumn{7}{|c|}{ Aimed at reducing depletion of the ozone layer } & \multirow{2}{*}{ Basic } \\
\hline & & & & & & & & \\
\hline $\begin{array}{l}\text { Optimize } \\
\text { Energy } \\
\text { Performance }\end{array}$ & \multicolumn{7}{|c|}{$\begin{array}{l}\text { Aims to raise the performance of energy higher than the basic limit to } \\
\text { reduce the adverse impact on the environment and the economy from } \\
\text { excessive use of energy }\end{array}$} & $19 / 19$ \\
\hline $\begin{array}{l}\text { Renewable } \\
\text { energy on site }\end{array}$ & \multicolumn{7}{|c|}{$\begin{array}{l}\text { Aims to promote and recognize the increase in levels of renewable energy } \\
\text { use on-site for self-sufficient clean energy, to reduce the adverse impact } \\
\text { on the environment and the economy from the use of fossil fuels }\end{array}$} & $7 / 7$ \\
\hline $\begin{array}{l}\text { Enhanced } \\
\text { Commissioning }\end{array}$ & \multicolumn{7}{|c|}{$\begin{array}{l}\text { Aims to initiate the recruitment process during the design and } \\
\text { implementation phase of some tasks after the completion of the } \\
\text { verification phase }\end{array}$} & $2 / 2$ \\
\hline \multirow{2}{*}{$\begin{array}{l}\text { Enhanced } \\
\text { Refrigerant } \\
\text { Management }\end{array}$} & \multicolumn{7}{|c|}{$\begin{array}{l}\text { Aiming to reduce depletion of the ozone layer during all operations } \\
\text { above the baseline limit }\end{array}$} & \multirow[t]{2}{*}{$2 / 2$} \\
\hline & & & & & & & & \\
\hline $\begin{array}{l}\text { Measurement } \\
\text { and Verification }\end{array}$ & \multicolumn{7}{|c|}{$\begin{array}{l}\text { The aim is to provide the building with energy consumption meters } \\
\text { permanently }\end{array}$} & $3 / 3$ \\
\hline Green Power & \multicolumn{7}{|c|}{$\begin{array}{l}\text { Aims to promote the development and use of renewable energy } \\
\text { technologies on the basis of zero pollution }\end{array}$} & $2 / 2$ \\
\hline $\begin{array}{l}\text { LEED } \\
\text { V.3-2009 NC }\end{array}$ & \multicolumn{7}{|c|}{ Renewable energy with sustainable future architecture } & $\begin{array}{l}\text { Total } \\
\text { points } \\
\text { added }\end{array}$ \\
\hline \multirow{2}{*}{$\begin{array}{l}\text { 4- Indoor } \\
\text { Environment } \\
\text { Quality }\end{array}$} & \multirow{2}{*}{$\begin{array}{l}\text { Solar } \\
\text { Energy }\end{array}$} & \multirow{2}{*}{$\begin{array}{l}\text { Wind } \\
\text { Energy }\end{array}$} & \multirow{2}{*}{$\begin{array}{l}\text { Ocean } \\
\quad \& \\
\text { Waves } \\
\text { Energy }\end{array}$} & \multirow{2}{*}{$\begin{array}{l}\text { Biomass } \\
\text { Energy }\end{array}$} & \multirow{2}{*}{$\begin{array}{c}\text { waste } \\
\text { material } \\
\text { Energy }\end{array}$} & \multirow{2}{*}{$\begin{array}{l}\text { Hydropow } \\
\text { er Energy }\end{array}$} & \multirow{2}{*}{$\begin{array}{l}\text { Geo } \\
\text { ther } \\
\text { mal } \\
\text { Ene } \\
\text { rgy }\end{array}$} & $13 / 15$ \\
\hline & & & & & & & & $8 / 15$ \\
\hline $\begin{array}{l}\text { Monitor } \\
\text { ventilation rate }\end{array}$ & \multicolumn{7}{|c|}{$\begin{array}{l}\text { Aims to provide the building with a ventilation control system to ensure } \\
\text { the health and safety of the population in a sustainable manner }\end{array}$} & $1 / 1$ \\
\hline $\begin{array}{l}\text { Monitor } \\
\text { ventilation rate }\end{array}$ & \multicolumn{7}{|c|}{$\begin{array}{l}\text { Aims to provide external ventilation to improve indoor air quality for the } \\
\text { comfort, health and productivity of the population }\end{array}$} & $1 / 1$ \\
\hline \multirow{2}{*}{$\begin{array}{l}\text { Construction } \\
\text { Indoor Air } \\
\text { Quality } \\
\text { Management } \\
\text { Plan (During } \\
\text { Construction - } \\
\text { Before } \\
\text { Occupancy) }\end{array}$} & \multicolumn{7}{|c|}{$\begin{array}{l}\text { Aimed at reducing the problems of indoor air quality resulting from the } \\
\text { construction or restoration process for the convenience and health of } \\
\text { workers and residents }\end{array}$} & \multirow[b]{2}{*}{$1 / 1$} \\
\hline & & & & & & & & \\
\hline $\begin{array}{l}\text { Use low emission } \\
\text { materials }\end{array}$ & \multicolumn{7}{|c|}{$\begin{array}{l}\text { The aim is to reduce the amount of indoor air pollutants such as bad } \\
\text { smell and harmful to the comfort and health of workers, users and } \\
\text { occupants of the building. }\end{array}$} & $4 / 4$ \\
\hline
\end{tabular}




\begin{tabular}{|c|c|c|c|c|c|c|c|c|}
\hline \multirow{2}{*}{$\begin{array}{l}\text { Indoor } \\
\text { Chemical and } \\
\text { Pollutant Source } \\
\text { Control }\end{array}$} & \multicolumn{7}{|c|}{$\begin{array}{l}\text { Aimed at reducing the exposure of the building population to hazardous } \\
\text { substances and chemical pollutants }\end{array}$} & \multirow{2}{*}{$\mathbf{0} / \mathbf{1}$} \\
\hline & & & & & & & & \\
\hline \multirow{2}{*}{$\begin{array}{l}\text { Use of } \\
\text { controllable } \\
\text { systems } \\
\text { (Lighting - } \\
\text { Thermal } \\
\text { Comfort) } \\
\end{array}$} & \multicolumn{7}{|c|}{$\begin{array}{l}\text { Aims to provide high level of control of lighting and air conditioning } \\
\text { systems by individual population or groups by place to raise the } \\
\text { productivity, comfort and health of the residents of the building }\end{array}$} & \multirow{2}{*}{$2 / 2$} \\
\hline & & & & & & & & \\
\hline $\begin{array}{l}\text { Achieve thermal } \\
\text { comfort (Design } \\
\text { - Verification) }\end{array}$ & \multicolumn{7}{|c|}{$\begin{array}{l}\text { Designed to provide buildings with convenient thermal systems to } \\
\text { improve the productivity and health of the occupants of the building } \\
\text { through the design of the building envelope and systems capable of } \\
\text { giving optimal performance to the factors of comfort under } \\
\text { environmental conditions and the expected use of the building. }\end{array}$} & \multirow[b]{2}{*}{$2 / 2$} \\
\hline $\begin{array}{l}\text { Natural lighting } \\
\text { and vision }\end{array}$ & \multicolumn{7}{|c|}{$\begin{array}{l}\text { The aim is to provide residents of the building a link between the } \\
\text { interior spaces with the exterior by bringing the lighting nature and } \\
\text { landscapes of the traditionally inhabited spaces of the building }\end{array}$} & \\
\hline $\begin{array}{l}\text { LEED } \\
\text { V.3-2009 NC }\end{array}$ & \multicolumn{7}{|c|}{ Renewable energy with sustainable future architecture } & $\begin{array}{l}\text { Total } \\
\text { points } \\
\text { added }\end{array}$ \\
\hline \multirow{2}{*}{$\begin{array}{l}\text { 5- Innovation } \\
\text { \&Design Process }\end{array}$} & \multirow{2}{*}{$\begin{array}{c}\text { Solar } \\
\text { Energy }\end{array}$} & \multirow{2}{*}{$\begin{array}{l}\text { Wind } \\
\text { Energy }\end{array}$} & \multirow{2}{*}{$\begin{array}{l}\text { Ocean } \\
\& \\
\text { Waves } \\
\text { Energy }\end{array}$} & \multirow{2}{*}{$\begin{array}{l}\text { Biomass } \\
\text { Energy }\end{array}$} & \multirow{2}{*}{$\begin{array}{l}\text { waste } \\
\text { material } \\
\text { Energy }\end{array}$} & \multirow{2}{*}{$\begin{array}{l}\text { Hydropow } \\
\text { er Energy }\end{array}$} & \multirow{2}{*}{$\begin{array}{l}\text { Geo } \\
\text { ther } \\
\text { mal } \\
\text { Ene } \\
\text { rgy }\end{array}$} & $6 / 6$ \\
\hline & & & & & & & & $6 / 6$ \\
\hline $\begin{array}{l}\text { Innovation in } \\
\text { Design }\end{array}$ & \multicolumn{7}{|c|}{$\begin{array}{l}\text { Designed to provide design and project teams with the opportunity to } \\
\text { score points for outstanding performance beyond the system } \\
\text { requirements for new green buildings }\end{array}$} & $5 / 5$ \\
\hline $\begin{array}{l}\text { LEED } \\
\text { Accredited }\end{array}$ & \multicolumn{7}{|c|}{$\begin{array}{l}\text { Aims to support and encourage the integration of design required by the } \\
\text { new green building appraisal system }\end{array}$} & \multirow[t]{2}{*}{$1 / 1$} \\
\hline Professional & & & & & & & & \\
\hline $\begin{array}{l}\text { LEED } \\
\text { V.3-2009 NC }\end{array}$ & & newable & nergy wi & sustainab & future ar & hitecture & & $\begin{array}{l}\text { Total } \\
\text { points } \\
\text { added }\end{array}$ \\
\hline \multirow[t]{2}{*}{$\begin{array}{l}\text { 6- Materials and } \\
\text { Resources }\end{array}$} & \multirow[t]{2}{*}{$\begin{array}{c}\text { Solar } \\
\text { Energy }\end{array}$} & \multirow[t]{2}{*}{$\begin{array}{l}\text { Wind } \\
\text { Energy }\end{array}$} & \multirow{2}{*}{$\begin{array}{l}\text { Ocean } \\
\& \\
\text { Waves } \\
\text { Energy }\end{array}$} & \multirow[t]{2}{*}{$\begin{array}{l}\text { Biomass } \\
\text { Energy }\end{array}$} & \multirow{2}{*}{$\begin{array}{c}\text { waste } \\
\text { material } \\
\text { Energy }\end{array}$} & \multirow{2}{*}{$\begin{array}{l}\text { Hydrop } \\
\text { ower } \\
\text { Energy }\end{array}$} & \multirow{2}{*}{$\begin{array}{l}\text { Geothe } \\
\text { rmal } \\
\text { Energy }\end{array}$} & $11 / 14$ \\
\hline & & & & & & & & $4 / 14$ \\
\hline \multirow{2}{*}{$\begin{array}{l}\text { Storage and } \\
\text { collection of } \\
\text { recyclable } \\
\text { materials }\end{array}$} & \multicolumn{7}{|c|}{$\begin{array}{l}\text { Designed to facilitate the reduction of waste by the residents of the } \\
\text { building and collected and dumped in the landfill }\end{array}$} & \multirow{2}{*}{ Basic } \\
\hline & & & & & & & & \\
\hline $\begin{array}{l}\text { Reuse the } \\
\text { building }\end{array}$ & \multicolumn{7}{|c|}{$\begin{array}{l}\text { Aimed at prolonging the building's lifecycle, conserving resources, } \\
\text { conserving cultural resources, minimizing waste and reducing the } \\
\text { negative environmental impact of new buildings in the manufacture, } \\
\text { transport and recycling of materials }\end{array}$} & $4 / 4$ \\
\hline
\end{tabular}




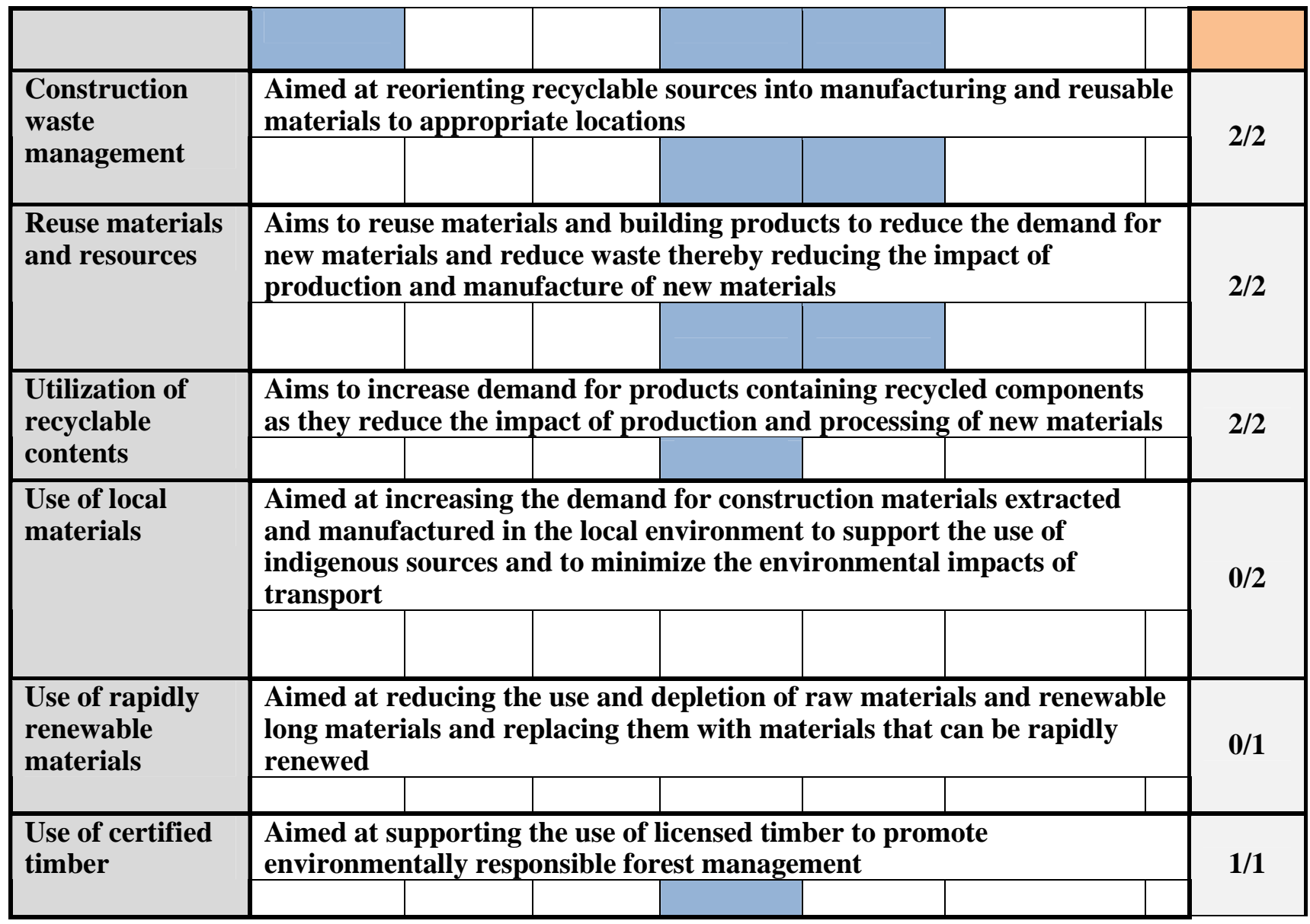

\begin{tabular}{|c|c|c|c|c|c|c|c|c|}
\hline $\begin{array}{c}\text { LEED } \\
\text { V 3-2009 NC }\end{array}$ & \multicolumn{7}{|c|}{ Renewable energy with sustainable future architecture } & \multirow{2}{*}{$\begin{array}{r}\text { Total } \\
\text { points } \\
\text { added }\end{array}$} \\
\hline $\begin{array}{l}\text { 7- Regional } \\
\text { priority }\end{array}$ & Solar Energy & $\begin{array}{l}\text { Wind } \\
\text { Energy }\end{array}$ & $\begin{array}{l}\text { Ocean } \\
\& \\
\text { Waves } \\
\text { Energy }\end{array}$ & $\begin{array}{l}\text { Biomass } \\
\text { Energy }\end{array}$ & $\begin{array}{c}\text { waste } \\
\text { material } \\
\text { Energy }\end{array}$ & $\begin{array}{l}\text { Hydropower } \\
\text { Energy }\end{array}$ & $\begin{array}{c}\text { Geothermal } \\
\text { Energy }\end{array}$ & \\
\hline $\begin{array}{l}\text { Regional } \\
\text { priorities }\end{array}$ & \multicolumn{7}{|c|}{$\begin{array}{l}\text { The aim is to increase the relative weight of the standards related to the } \\
\text { regional environmental significance, and to encourage the application of those } \\
\text { standards that meet the needs of the areas in which they exist and are } \\
\text { effectively adapted to their nature. }\end{array}$} & $4 / 4$ \\
\hline $\begin{array}{r}\bullet \\
-\quad \text { Tota } \\
\end{array}$ & $\begin{array}{l}\text { otal points } \\
\text { oints gained }\end{array}$ & y using & eotherr & $\begin{array}{l}\text { d Energy } \\
\text { I Energy }\end{array}$ & $=43 / 110$ & $\begin{array}{l}\text { ies }=88 / 110 \\
\text { ints }=\text { Golde } \\
\text { ints }=\text { Golde } \\
\text { ertified clas }\end{array}$ & $\begin{array}{l}\text { ints } \\
\text { classificatic } \\
\text { classificatic } \\
\text { ication }\end{array}$ & \\
\hline
\end{tabular}

\section{CONCLUSION}

The number of LEED Sustainability Score points gained from the integration of the renewable energies with the building is up to $\mathbf{8 8}$ points from the total points of the system. The number of points earned is sufficient to qualify the building to reach the classification of the advanced system, which is the platinum classification of one rank less than the highest category of assessment is the platinum rating, a distinctive indicator of the strength of the level of environmental performance of the building. 
in additional, it was found that the number of points earned from applying (Solar Energy) is up to $\mathbf{7 3}$ points to reach golden classification, (Wind Energy) is up to $\mathbf{6 6}$ points to reach golden classification and (Geothermal Energy) is up to $\mathbf{4 3}$ points to reach certified classification.

Renewable energies contribute to the provision of innovative future solutions the ability to change the physical and mechanical properties of the traditional building design and have significant environmental and economic effects in the medium and long term of the building's and take into account the achievement of elements of speed.

From the previous analysis and conclusions, the following can be found: There is a positive relationship between the use of properties acquired by the renewable energies as a complementary technique in the field of energy efficiency in buildings and the adoption of sustainable buildings design.

\section{REFERENCES}

1. (NREL), N. R. E. L., 2018. National Renewable Energy Laboratory (NREL) Home Page. [Online] Available at: http://www.nrel.gov [Accessed 2810 2018].

2. Ahmed, S., 2015. Wind energy: theory and practice. s.1.:PHI Learning Pvt. Ltd..

3. Asumadu-Sarkodie, S. a. O. P. A., 2016. Carbon dioxide emissions, GDP, energy use, and population growth: a multivariate and causality analysis for Ghana, 1971--2013. Environmental Science and Pollution Research, pp. 13508--13520.

4. Asumadu-Sarkodie, S. a. O. P. A., 2016. The potential and economic viability of wind farms in Ghan. Energy sources, Part A: Recovery, utilization, and environmental effects, pp. 695--701.

5. Ayoub, M. a. A. A. Z., 2012. Critical review on the current scenario and significance of crude glycerol resulting from biodiesel industry towards more sustainable renewable energy industry. Renewable and Sustainable Energy Reviews, pp. 2671--2686.

6. Barbier, E., 2002. Geothermal energy technology and current status: an overview. Renewable and sustainable energy reviews, pp. 3--65.

7. Boyle, G., 2004. Renewable energy. Renewable Energy, by Edited by Godfrey Boyle, pp. 456. Oxford University Press, May 2004. ISBN-10: 0199261784. ISBN-13: 9780199261789 , p. 456.

8. Bull, S. R., 2001. Renewable energy today and tomorrow. Proceedings of the IEEE, pp. 1216--1226.

9. Cohen, B. a. W. M. I., 2007. Market imperfections, opportunity and sustainable entrepreneurship. Journal of Business Venturing, pp. 29--49.

10. Council, W. E., 2013. World energy resources. London: World Energy Council.

11. Demirbas, M. F. a. B. M. a. B. H., 2009. Potential contribution of biomass to the sustainable energy development. Energy Conversion and Management, pp. 1746--1760.

12. Edenhofer, O. a. P.-M. R. a. S. Y. a. S. K. a. K. S. a. Z. T. a. E. P. a. H. G. a. S. S. a. v. S. C. a. o., 2011. Renewable energy sources and climate change mitigation: Special report of the intergovernmental panel on climate change. s.l.:Cambridge University Press.

13. Edenhofer, O. a. P.-M. R. a. S. Y. a. S. K. a. M. P. a. K. S. a. Z. T. a. E. P. a. H. G. a. S. S. a. o., 2011. IPCC special report on renewable energy sources and climate change mitigation. Prepared By Working Group III of the Intergovernmental Panel on Climate Change, Cambridge University Press, Cambridge, UK.

14. Esteban, M. a. L. D., 2012. Current developments and future prospects of offshore wind and ocean energy. Applied Energy, pp. 128--136.

15.F $\{\backslash$ o $\}$ rsund, F. R., 2015. Pumped-storage hydroelectricity / Hydropower Economics. s.l.:Springer.

16. Hoogwijk, M. a. F. A. a. E. B. a. d. V. B. a. T. W., 2005. Potential of biomass energy out to 2100 , for four IPCC SRES land-use scenarios. Biomass and Bioenergy, pp. 225--257.

17. Jacobson, M. Z. a. D. M. A., 2011. Providing all global energy with wind, water, and solar power, Part I: Technologies, energy resources, quantities and areas of infrastructure, and materials. Energy policy, pp. 1154--1169.

18. Jeans, T. L., Fagley, C., Siegel, S. \& Seidel, J., 2013. Irregular deep ocean wave energy attenuation using a cycloidal wave energy converter. International Journal of Marine Energy, , 1(), pp. 16-32. 
19. Johari, A. a. A. S. I. a. H. H. a. A. H. a. R. M., 2012. Economic and environmental benefits of landfill gas from municipal solid waste in Malaysia. Renewable and Sustainable Energy Reviews, pp. 2907--2912.

20. Shepherd, W. a. Z. L., 2011. Electricity generation using wind power. s.1.:World scientific. 21. Urban, F. a. M. T., 2011. Climate change, disasters and electricity generation. IDS.

22.Zin, A. A. B. M. a. H. M. P. a. K. A. B. a. J. L. a. S. O., 2013. An overview on doubly fed induction generators' controls and contributions to wind based electricity generation. Renewable and Sustainable Energy Reviews, pp. 692--708. 